\title{
Mesenchymal stem cell therapy in the treatment of acute and chronic graft versus host disease
}

\section{Partow Kebriaei* and Simon Robinson}

Department of Stem Cell Transplantation and Cellular Therapy, University of Texas MD Anderson Cancer Center, Houston, TX, USA

\section{Edited by:}

Marcos De Lima, MDACC, USA

Reviewed by:

Nelson Hamerschlak, Hospital Israelita

Albert Einstein, Brazil

Paul Armistead, University of North

Carolina, USA

${ }^{*}$ Correspondence:

Partow Kebriaei, University of Texas MD Anderson Cancer Center, Unit 423, 1515 Holcombe Blvd., Houston, TX 77030, USA.

e-mail:pkebriae@mdanderson.org
Mesenchymal stem cells (MSC) are a cellular component of the supportive microenvironment (stroma) found in the bone marrow, umbilical cord, placenta, and adipose tissues. In addition to providing cellular and extracellular cues to support the proliferation and differentiation of cells that comprise functional tissues, MSC also contribute to tissue repair and have immunomodulatory properties. Their ability to modulate immunologic reactions while themselves not provoking immunologic responses from alloreactive T-lymphocytes and/or other effector cells, make MSC a potentially ideal therapeutic agent with which to treat graft versus host disease (GvHD) following hematopoietic transplantation. Despite in vitro experiments confirming that MSC suppress mixed lymphocyte reactions (MLR) and in vivo evidence from mouse models that show evidence that MSC can ameliorate GVHD, clinical trials to date using MSC to treat GvHD have shown mixed results. Whether this is a consequence of suboptimal timing and dose of administered MSC remains to be clarified. It is clear that immunomodulatory potential of MSC as a cellular therapy for G VHD remains to be realized in the clinic.

Keywords: mesenchymal stem cell, graft versus host disease, animal models, clinical trials

\section{INTRODUCTION}

Mesenchymal stem cells (MSC) are a population of phenotypically heterogeneous cells that are an important cellular component of the supportive stromal microenvironment within functional tissues. They have the capacity to differentiate into osteoblasts, chondroblasts, and adipocytes in vitro (Pittenger et al., 1999; Jiang et al., 2002; Horwitz et al., 2005; Dominici et al., 2006) and since they do not express class II human histocompatibility antigens (HLA-II), or accessory molecules (CD40, CD80, and CD86) they do not provoke an immunologic response if transplanted. As a consequence, HLA matching does not present as a major hurdle against their use in cellular therapies (Le Blanc et al., 2003). In addition, MSC have the capacity to modulate immune reactions (Di Nicola et al., 2002; Aggarwal and Pittenger, 2005; Ramasamy et al., 2008; Uccelli et al., 2008), are important for effective tissue repair and regeneration (Deans and Moseley, 2000; Horwitz et al., 2002; Toma et al., 2002) and can be isolated, expanded, and purified ex vivo, from many tissues including bone marrow (McNiece et al., 2004; Robinson et al., 2006; Najar et al., 2010a), umbilical cord (Majore et al., 2011; Najar et al., 2010a,b; Tong et al., 2010), placenta (Zhang et al., 2004a), and adipose tissue (Najar et al., 2010a,b). Since immunoprivileged MSC do not provoke immunologic responses in an HLA-unmatched recipient and are able to modulate immunologic interactions, they are an attractive candidate as a potential cellular therapy for the treatment of graft versus host disease $(\mathrm{G} v \mathrm{HD})$. GvHD remains a significant cause of morbidity and mortality following allogeneic hematopoietic stem cell transplantation and any therapy that might ameliorate or eliminate the symptoms of $\mathrm{G} v \mathrm{HD}$, especially steroid-refractory $\mathrm{G} v \mathrm{HD}$, would have great clinic significance.

\section{MSC AS IMMUNOMODULATORS}

Mesenchymal stem cells possess intrinsic immunoregulatory activities that, while not yet fully characterized, broadly modulate innate and adaptive immune responses (Uccelli et al., 2008; Auletta et al., 2010). Within the context of innate immunity, MSC alter antigen-presenting cell (APC) development, maturation, and function. Dendritic cells (DC) are potent APC for naïve T-cells, and are critical in donor T-cell activation during acute G $v$ HD (Shlomchik, 2007). MSC inhibit differentiation of monocytes to DC, and furthermore, affect DC differentiation, activation, and function (Uccelli et al., 2008). MSC also inhibit natural killer (NK) cell proliferation and cytokine production, and could potentially modulate DC function through their effects on NK cells (Spaggiari et al., 2006). In the light of these effects, MSC might suppress allo-reactivation of donor T-cells against the host in the setting of $\mathrm{G} v \mathrm{HD}$, although acute $\mathrm{G} v \mathrm{HD}$ typically results in high levels of interferon gamma (IFN $\gamma$ ) which may increase MHC class II expression on MSC (Shlomchik, 2007; Welniak et al., 2007) and could paradoxically compound the development of G $v \mathrm{HD}$.

Within the context of adaptive immunity, MSC inhibit alloreactive T-cell responses via contact-dependent mechanisms and soluble factors (Keating, 2008; Uccelli et al., 2008). Some studies suggest MSC effect a shift in T-cell function toward a more regulatory phenotype (Prevosto et al., 2007). Importantly, the effects of MSC on T-cells are independent of HLA matching between MSC and lymphocytes (Le Blanc et al., 2003; Sundin et al., 2009) and MSC can be administered repeatedly without provoking an immunologic response from the recipient (Sundin et al., 2009). 


\section{MSC AND TISSUE REPAIR}

Currently, the role of MSC in tissue repair and regeneration is under extensive study. Of specific relevance to mechanisms associated with the development of $\mathrm{G} v \mathrm{HD}$, a number of animal models of injury including cerebral ischemia (Li et al., 2010), total body irradiation (Chapel et al., 2003; Devine et al., 2003), and myocardial infarction (Pittenger and Martin, 2004) have demonstrated a chemotactic response of MSC to the site of injury. Such sites of injury might include lesions associated with GvHD. Once at the site of injury, or inflammation, it has been proposed that MSC can stimulate tissue repair (Prockop and Olson, 2007).

\section{IMMUNOMODULATORY ROLE FOR MSC IN MURINE MODELS OF G vHD}

Murine models have been used to investigate the immunomodulatory potential of MSC in ameliorating (preventing and/or treating) $\mathrm{G} v \mathrm{HD}$. Such studies have revealed a mix of results with some showing immunomodulatory efficacy and others not (Chung et al., 2004; Sudres et al., 2006; Min et al., 2007; Tisato et al., 2007). However, they have highlighted a number of important questions which might impact the clinical efficacy of MSC as a cellular therapy for GvHD. Such questions include:

(a) Defining the optimal dose of MSC,

(b) Determining the correct time for administration of MSC, and

(c) Studying the biodistribution of MSC.

(a) Defining the optimal dose of MSC: Given that the number of MSC available for transplant is likely a limiting factor, the target doses that should be utilized to ameliorate $\mathrm{G} v \mathrm{HD}$ in the clinic become an important consideration. Using the mixed lymphocyte reaction (MLR) optimal inhibition of splenocyte proliferation was achieved in the presence of MSC at a ratio of 0.5-1 MSC: 1 splenocyte (Joo et al., 2010). MSC were administered into a murine model of $\mathrm{G} v \mathrm{HD}$ at this ratio. $\mathrm{G} v \mathrm{HD}$ was established in lethally irradiated $\mathrm{BALB} / \mathrm{c}$ mice when $5 \times 10^{6}$ bone marrow cells and $1 \times 10^{6}$ spleen cells from $\mathrm{C} 3 \mathrm{H} /$ he donor mice were injected. In this model, death occurred after 12 days due to severe acute $\mathrm{G} v \mathrm{HD}$. Against this background, mice also received $0.5 \times 10^{6}$ MSC (low dose), $1.0 \times 10^{6}$ MSC (intermediate dose), or $2.0 \times 10^{6} \mathrm{MSC}$ (high dose) at the time that $1 \times 10^{6}$ spleen cells were infused. These doses reflect MSC:splenocyte ratios of $0.5: 1,1: 1$, and 2:1. While the low dose of MSC did not prevent death, the survival rate of mice receiving the intermediate and high doses of MSC were significantly improved (Joo et al., 2010).

Consistent with previous findings (Casiraghi et al., 2008; Di Ianni et al., 2008; Ye et al., 2008; Gonzalez-Rey et al., 2010), the beneficial impact of MSC administration in this GvHD model appeared to be, at least in part, to an MSC-associated activation of regulatory T-cells $\left(\mathrm{T}_{\text {Reg }}\right)$. Indeed, an increase in $\mathrm{T}_{\text {Reg }}$ numbers $\left(\mathrm{CD} 4^{+} 25^{+}\right.$Foxp $3^{+}$cells) was observed in vivo in mice receiving both splenocytes and MSC as compared to those receiving splenocytes alone (Joo et al., 2010). It is thought that TGF $\beta$ secreted by the MSC may induce the proliferation and activation of $\mathrm{T}_{\mathrm{Reg}}$ (Keating, 2008;
Uccelli et al., 2008). Increased $\mathrm{T}_{\text {Reg }}$ activity is ultimately thought to suppress the activity of the donor T-cells that are ultimately responsible for the acute $\mathrm{G} v \mathrm{HD}$ observed, thereby ameliorating the symptoms of the disease and improving the survival rate of the mice. The amount of any immunoregulatory factor liberated by the MSC is proportional to the numbers of MSC, therefore it is likely that a specific dose of MSC might be required before levels sufficient to maximally stimulate $\mathrm{T}_{\mathrm{Reg}}$ proliferation and ameliorate the symptoms of $\mathrm{G} v \mathrm{HD}$ are achieved in vivo. Recent data have further confirmed that there is an interaction between MSC and $\mathrm{T}_{\text {Reg }}$ (Kavanagh and Mahon, 2011). In this instance, MSC induce the proliferation and activation of $\mathrm{T}_{\mathrm{Reg}}$ in vivo and reduce a specific allergen-driven pathology.

(b) Determining the correct time for administration of MSC: Experiments have been performed to investigate the optimal timing for administration of MSC to best ameliorate the symptoms of $\mathrm{G} v \mathrm{HD}$. A murine GvHD model was generated by the transplant of lethally irradiated male BALB/c $\left(\mathrm{H}-2 \mathrm{~K}^{\mathrm{d}}\right)$ mice with bone marrow and splenocytes from female C57BL/6 (H-2K b mice (Polchert et al., 2008). MSC were introduced into this model concurrently with bone marrow infusion, or 2, 20, or 30 days after bone marrow infusion. While mice died of the symptoms of acute GvHD when they received no MSC, death was also observed when MSC were administered at the time of bone marrow infusion (early time point), or 30 days after bone marrow infusion (late time point). However, when MSC were administered 2, or 20 days after bone marrow infusion, significantly increased survival rates were observed indicating that the administered MSC acted to ameliorate the symptoms of the acute GvHD (Polchert et al., 2008). The apparent failure of MSC to ameliorate the symptoms of $\mathrm{G} v \mathrm{HD}$ when administered early ( $<2$ days) was possibly due to levels of immunomodulatory factors being too low to elicit any beneficial effect. The apparent failure of MSC to ameliorate the symptoms of $\mathrm{G} v \mathrm{HD}$ when administered later (30 days) was possibly attributable to the presence of overwhelming numbers of activated T-cells at this time point. To explain the apparent "window" of opportunity for effective MSC immunomodulation of $\mathrm{G} v \mathrm{HD}$ and significantly increased survival rates (observed at 2 and 20 days after bone marrow infusion), it is suggested that a pro-inflammatory milieu needs time to develop. Within this milieu the MSC become activated. MSC are activated by IFN $\gamma$ (Croitoru-Lamoury et al., 2007) and their migration might be driven, at least in part, by an IFN $\gamma$-associated upregulation of chemokine receptors expressed by MSC (New et al., 2002; Wang et al., 2002). Once activated, MSC are possibly drawn to sites of T-cell activation where they may block interactions between donor T-cells and DC which may prevent the activation of the donor T-cells thereby ameliorating the symptoms of $\mathrm{G} v \mathrm{HD}$ (Zhang et al., 2004b; Aggarwal and Pittenger, 2005; Beyth et al., 2005; Gur-Wahnon et al., 2007). The importance of IFN $\gamma$ in this activation process was shown when bone marrow and splenocytes were transplanted from IFN $\gamma$ knockout mice. In the absence of IFN $\gamma$ MSC were not activated and failed to immunosuppress the donor T-cells leading to 
the development of $\mathrm{G} v \mathrm{HD}$, irrespective of the time or dose of administration (Polchert et al., 2008). Given that IFN $\gamma$ appears to have an important role in the activation of MSC and given that serum levels of IFN $\gamma$ the factor remained low for up to 2 days after transplantation (Polchert et al., 2008), it is perhaps not a surprising observation that MSC administered early ( $<2$ days) fail to ameliorate G $v$ HD. These data provide strong evidence that the time of administration of MSC after transplant is a critical consideration if effective amelioration of GvHD is to be achieved.

(c) Studying the biodistribution of MSC: Imaging can be used to reveal the biodistribution of MSC in murine models of $\mathrm{G} v \mathrm{HD}$ (Joo et al., 2011). In one such model, recipient BALB/c-nude mice received a lethal $500 \mathrm{cGy}$ radiation dose and $5 \times 10^{6} \mathrm{BM}$ cells from normal C57BL/6 donor mice. To induce G $v \mathrm{HD}$, $1 \times 10^{6}$ splenocytes from C57BL/6 donor mice expressing the enhanced green fluorescent protein (EGFP) was injected. EGFP signal allowed the trafficking of splenocytes and identified sites of GvHD in situ. To study the biodistribution of MSC in this model, MSC were generated from C57BL/6 donor mice expressing red fluorescent protein (RFP). RFPMSC were transplanted at $1 \times 10^{6} \mathrm{MSC} /$ mouse. All cells were injected into the lethally irradiated $\mathrm{BALB} / \mathrm{c}$-nude mice within $24 \mathrm{~h}$ of irradiation. After 2 days, EGFP signal, associated with donor splenocytes, was detected in the lungs. At this same time point RFP signal associated with MSC was also detected in the lungs (Gao et al., 2001; Lee et al., 2009; Joo et al., 2011). After 7 days, EGFP (splenocyte) signal intensity reduced in the lungs and increased in the GI tract. A similar change in the pattern of RFP (MSC) signal intensity was observed. After 22-37 days, EGFP and RFP signals colocalized to the liver, skin, and lymph nodes, illustrating that MSC can home to sites of progressive and on-going G $v \mathrm{HD}$ and thereby potentially exert direct cell-cell contact mediated and/or indirect paracrine immunosuppressive effects.

\section{NO EVIDENCE OF AN IMIMUNOMODULATORY ROLE FOR MSC IN A CANINE MODEL OF G vHD}

While the mouse provides genetically well-defined models with which to investigate the immunomodulatory role of MSC against experimentally induced $\mathrm{G} v \mathrm{HD}$ in vivo, the use of less rigorously defined models might be more representative of clinical transplantation. When such a model (canine) is used, researchers report no benefit associated with MSC administration in the treatment of $\mathrm{G} v \mathrm{HD}$ and prevention of graft rejection (Mielcarek et al., 2011). These negative observations were made despite the demonstration of in vitro suppressive activity in canine MLR experiments by allogeneic canine MSC and despite the observation that that the pattern of allogeneic canine MSC distribution in vivo in canine recipients was similar to that observed in mice after intravenous administration of mouse MSC (namely accumulation in lungs immediately after administration followed by redistribution to GI tract, liver, spleen and bone marrow). The failure to demonstrate any benefit associated with MSC administration in this dog model also occurred despite frequent, repeated MSC administration (2-3 doses/week) at doses of up to $30 \times 10^{6} \mathrm{MSC} / \mathrm{kg}$ which is somewhat inconsistent with data from murine studies which suggest that timing and dose of MSC administration are critical if optimal immunomodulation of GvHD by MSC is to be achieved (Mielcarek et al., 2011).

\section{CLINICAL TRIALS WITH MSC TO TREAT G VHD}

Clinical trials were developed based on the pre-clinical data with the limitations inherent to murine models (summarized in Tables 1-3). MSC therapies have been most extensively studied in steroid-refractory $\mathrm{G} v \mathrm{HD}$. The first case of successful treatment of severe refractory acute $\mathrm{G} v \mathrm{HD}$ of the gut and liver in a pediatric patient using ex vivo expanded haplo-identical human MSC was reported by Le Blanc et al. (2004). While a prompt amelioration of $\mathrm{G} v \mathrm{HD}$ was observed after the administration of MSC, symptoms recurred. However, these symptoms were responsive to a second administration of MSC (Le Blanc et al., 2004). Of eight patients with steroid-refractory $\mathrm{G} v \mathrm{HD}$ that were subsequently treated with MSC a complete response (CR) was achieved in six patients (75\%). One month after MSC administration, analysis of a colon biopsy from one of the six patients in CR revealed DNA from the donor MSC (Ringden et al., 2006). These encouraging results were subsequently corroborated in a non-randomized, multicenter trial reported by the European Blood and Marrow Transplant MSC consortium (Le Blanc et al., 2008).

\section{EUROPEAN BLOOD AND MARROW TRANSPLANT MSC STUDY}

The EBMT MSC trial shared expansion protocols and common reagents and 25 pediatric and 30 adult patients with steroidrefractory $\mathrm{G} v \mathrm{HD}$ were treated with MSC. MSC were derived from HLA-identical and haplo-identical sibling donor bone marrow, or third-party mismatched, bone marrow. A single median dose of $1.4 \times 10^{6} \mathrm{MSC} / \mathrm{kg}$ was given and a $70 \%$ initial response rate (complete or partial remission) was achieved. First response was observed after a median of 18 days of MSC administration. Patients that responded to the MSC therapy and achieved CR at 6 weeks had a statistically significant reduced level of treatment-related mortality (TRM) at the 1-year time point when compared to patients that did not respond ( 37 vs. $72 \%, P=0.002$, respectively). Further, overall survival (OS) was also significantly improved in patients in CR after MSC therapy, when compared to patients that did not respond (53 vs. $16 \%, P=0.018$, respectively; Le Blanc et al., 2008). MSC infusions were well tolerated and no significant adverse events were reported. Responses in pediatric patients were generally better than adult patients, with a statistical improvement in survival achieved. Since most patients received third-party (unmatched) donor MSC and achieved encouraging amelioration of GvHD, these data suggests that any concerns regarding HLA disparity between donor and recipient are of little significance.

\section{PHASE II CLINICAL TRIALS OF THIRD-PARTY MSC TO AMELIORATE STEROID-REFRACTORY ACUTE G VHD}

Further to the EBMT MSC trial, a pediatric phase II study of third-party, "off-the-shelf," mismatched MSC (Prochymal ${ }^{\circledR}$, Osiris Therapeutics, Inc.) for steroid-refractory acute G $v \mathrm{HD}$ has also been reported (Table 1). Fifty-nine patients (median age 8 years) with steroid-refractory acute $\mathrm{G} v \mathrm{HD}$ received 8 biweekly infusions of $2 \times 10^{6} \mathrm{MSC} / \mathrm{kg}$ for 4 weeks, followed by an additional 4 weekly infusions as "maintenance." The majority of patients presented 
Table 1 | Results of clinical trails utilizing MSC for steroid-refractory acute GvHD.

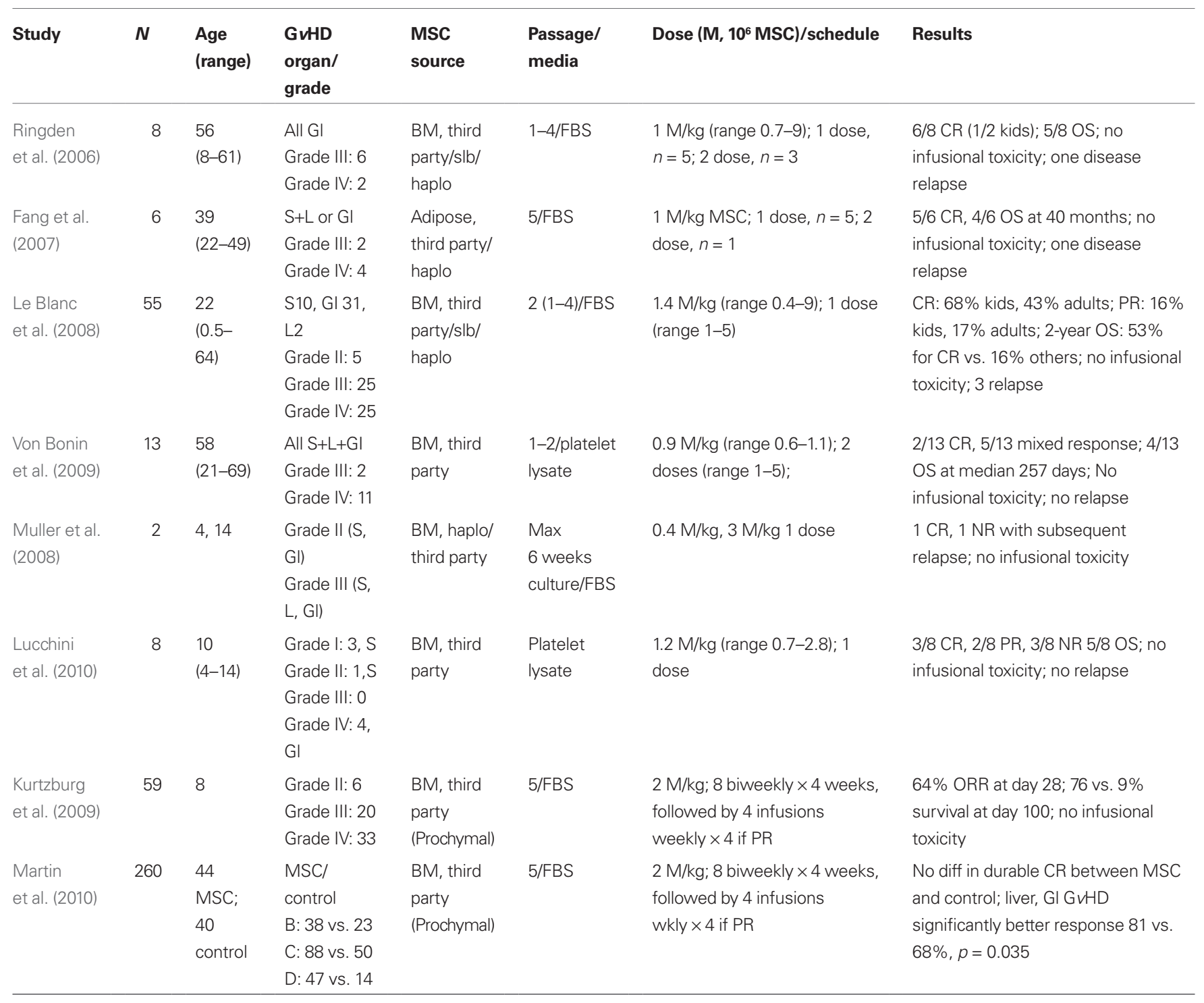

Table 2 | Results of clinical trails utilizing MSC for de novo acute GvHD.

\begin{tabular}{|c|c|c|c|c|c|c|c|}
\hline $\begin{array}{l}\text { Kebriaei } \\
\text { et al. (2009) }\end{array}$ & 32 & $\begin{array}{l}52 \\
(34-67)\end{array}$ & $\begin{array}{l}\text { Grade II: } 21 \\
\text { Grade III: } 8 \\
\text { Grade IV: } 3\end{array}$ & $\begin{array}{l}\text { BM, third } \\
\text { party } \\
\text { (Prochymal) }\end{array}$ & $5 / F B S$ & $\begin{array}{l}2 \text { or } 8 \mathrm{M} / \mathrm{kg} \text { at } 1 \text { and } 3 \text { days } \\
\text { after } \mathrm{G} v \mathrm{HD}+\text { steroids }\end{array}$ & $\begin{array}{l}\text { 94\% initial response (77\% CR, 16\% } \\
\text { PR), } 61 \% \text { sustained CR; No } \\
\text { difference between high/low MSC } \\
\text { dose; No infusional toxicity; three } \\
\text { disease relapse }\end{array}$ \\
\hline $\begin{array}{l}\text { Osiris } \\
\text { Therapeutics, } \\
\text { Inc. (2009) }\end{array}$ & 192 & 18-70 & $B-D$ & $\begin{array}{l}\text { BM, third } \\
\text { party } \\
\text { (Prochymal) }\end{array}$ & $5 / F B S$ & $\begin{array}{l}2 \mathrm{M} / \mathrm{kg} \text {; twice wkly } \times 2 \\
\text { weeks, followed by } \\
\text { weekly } \times 2 \text {; MSC vs. placebo }\end{array}$ & $\begin{array}{l}\text { No difference in durable CR } \\
\text { between MSC and placebo, } 45 \text { vs. } \\
46 \%\end{array}$ \\
\hline
\end{tabular}

with severe gut and liver $\mathrm{G} v \mathrm{HD}$, and had received prior therapy for $\mathrm{G} v \mathrm{HD}$. At day 28 , the overall response rate was $64 \%$ and patients that showed responses had a significantly better survival at the
100 day time point (76 vs. 9\%) as compared to patients who did not (Kurtzberg et al., 2009). Similar findings have been reported in other studies (Table 1; von Bonin et al., 2009). 
Table 3 | Results of clinical trails utilizing MSC for chronic GuHD.

\begin{tabular}{|c|c|c|c|c|c|c|c|}
\hline Study & $N$ & $\begin{array}{l}\text { Age } \\
\text { (range) }\end{array}$ & $\begin{array}{l}\text { GvHD organ/ } \\
\text { grade }\end{array}$ & $\begin{array}{l}\text { MSC } \\
\text { source }\end{array}$ & $\begin{array}{l}\text { Passage/ } \\
\text { media }\end{array}$ & Dose (M, $\left.10^{6} \mathrm{MSC}\right) /$ schedule & Results \\
\hline $\begin{array}{l}\text { Muller et al. } \\
\text { (2008) }\end{array}$ & 3 & $\begin{array}{l}15 \\
(15-17)\end{array}$ & $\begin{array}{l}\text { Extensive } \\
\text { chronic }\end{array}$ & $\begin{array}{l}\text { BM, third } \\
\text { party/sib/ } \\
\text { haplo }\end{array}$ & $\begin{array}{l}\text { Max } \\
6 \text { weeks } \\
\text { culture/FBS }\end{array}$ & $\begin{array}{l}2.0 \mathrm{M} / \mathrm{kg} \text { (range 1.4-3.0); } 1 \\
\text { dose, } n=1 ; 2 \text { dose, } n=2\end{array}$ & $\begin{array}{l}1 / 3 \text { improvement; no infusional } \\
\text { toxicity; no relapse }\end{array}$ \\
\hline $\begin{array}{l}\text { Lucchini } \\
\text { et al. (2010) }\end{array}$ & 5 & $\begin{array}{l}9 \\
(5-15)\end{array}$ & $\begin{array}{l}\text { Chronic } \\
\text { skin + mucosa, } \\
n=4 \text {; chronic } \\
\text { skin + liver, } \\
n=1\end{array}$ & $\begin{array}{l}\text { BM, third } \\
\text { party }\end{array}$ & $\begin{array}{l}\text { expanded in } \\
\text { platelet- } \\
\text { lysate } \\
\text { medium }\end{array}$ & $\begin{array}{l}\text { 1.1 M/kg (range 0.7-1.4); } 1 \\
\text { dose, } n=4 ; 2 \text { dose, } n=1\end{array}$ & $\begin{array}{l}\text { 1/5 CR with reflare, 2/5 PR, 2/5 } \\
\text { NR; no infusional toxicity; no } \\
\text { relapse; in vivo } \\
\text { immunomodulation noted in } \\
\text { responsive group }\end{array}$ \\
\hline $\begin{array}{l}\text { Zhou et al. } \\
\text { (2010) }\end{array}$ & 4 & $\begin{array}{l}42 \\
(38-43)\end{array}$ & $\begin{array}{l}\text { Extensive, } \\
\text { sclerodermal } \\
\text { features }\end{array}$ & $\begin{array}{l}\text { BM, third } \\
\text { party }\end{array}$ & 3-6/FBS & $\begin{array}{l}1-2 \times 10^{7} \mathrm{MSC} / \mathrm{kg} ; 4-8 \\
\text { intra-BM injections per patient }\end{array}$ & $\begin{array}{l}\text { 4/4 significant improvement; no } \\
\text { infusional toxicity }\end{array}$ \\
\hline $\begin{array}{l}\text { Weng et al. } \\
\text { (2010) }\end{array}$ & 19 & $\begin{array}{l}29 \\
(18-39)\end{array}$ & $\begin{array}{l}\text { Extensive } \\
\text { chronic }\end{array}$ & $\begin{array}{l}\text { BM, third } \\
\text { party }\end{array}$ & $2-3 / F B S$ & $\begin{array}{l}0.6 \mathrm{M} / \mathrm{kg} \text { (range } 0.2-1.4) ; 1-5 \\
\text { doses }\end{array}$ & $\begin{array}{l}\text { 74\% ORR (4 CR, } 10 \text { PR), five } \\
\text { patients able to stop } \\
\text { immunosuppression, } 2 \text { year OS } \\
\text { 78\%; in vivo immunomodulation } \\
\text { noted in responsive group }\end{array}$ \\
\hline
\end{tabular}

\section{MSC AS AN ADJUNCT TO STEROID THERAPY IN THE} TREATMENT OF STEROID RESPONSIVE ACUTE G VHD

While there are many reports of the use of MSC to treat steroidrefractory $\mathrm{G} v \mathrm{HD}$ (Table 1), there are fewer studies of MSC as an adjunct therapy for the treatment of steroid responsive acute GvHD (Table 2). The results of such a phase II trial for patients with grades II-IV acute GvHD have been reported (Kebriaei et al., 2009). Thirty-two adult patients received two treatments of MSC (Prochymal ${ }^{\circledR}$ ) at a dose of either 2 or $8 \times 10^{6} \mathrm{MSC} / \mathrm{kg}$ in combination with a conventional corticosteroid regimen. Patients continued to receive GvHD prophylaxis with tacrolimus, cyclosporine, or mycophenolate mofetil. Thirty-one patients were evaluable, with 94\% initial response rate noted (24 CR, 5 PR). Nineteen of $24 \mathrm{CR}$ were maintained for at least 90 days. No infusional toxicities or ectopic tissue formation were reported. While the trial was not designed to detect differences between the two MSC doses administered, no obvious differences were observed (Kebriaei et al., 2009).

\section{PHASE III CLINICAL TRIALS OF THIRD-PARTY MSC TO AMELIORATE STEROID SENSITIVE AND STEROID- REFRACTORY ACUTE G UHD}

Preliminary results from two multicenter, randomized, phase III clinical trials for de novo acute and steroid-refractory acute GvHD have been reported by Osiris Therapeutics, Inc. (2009). In both studies, third party, “off-the-shelf” MSC (Prochymal ${ }^{\circledR}$ ) were administered weekly or biweekly for 4 weeks with individual dosing at $2 \times 10^{6} \mathrm{MSC} / \mathrm{kg}$. Neither the steroid-refractory nor the newly diagnosed G $v \mathrm{HD}$ trials reached the primary endpoint of durable $\mathrm{CR} \geq 28$ days. However, select patients with steroid-refractory liver or gastrointestinal $\mathrm{G} v \mathrm{HD}$ were reported to have significantly improved response rates (81 vs. $68 \%, P=0.035)$. No significant difference was noted with respect to toxicity or recurrent malignancy rates (Martin et al., 2010).

\section{MSC AS A CELLULAR THERAPY TO AMELIORATE CHRONIC G VHD}

Experience with MSC for the treatment of chronic G $v \mathrm{HD}$ is more limited, and summarized in Table 3. One pediatric patient showed slight improvement after infusion of $3 \times 10^{6} \mathrm{MSC} / \mathrm{kg}$ administered 7 and 26 months after transplant (Muller et al., 2008). A second patient with extensive chronic GvHD was treated with $0.6 \times 10^{6}$ haplo-identical MSC/kg 5 months after transplant, but showed no response (Ringden et al., 2006). Of note, this patient and a patient with chronic G $v \mathrm{HD}$ treated with MSC in a previous study, died eventually of complications associated with the development of EBV-PTLD (Ringden et al., 2006; Muller et al., 2008). Consistent with observations that suggest only limited (if any) improvement in chronic G $v \mathrm{HD}$ following MSC infusion, reports from other pediatric patients with chronic GvHD of skin and mucosa treated with "off-the-shelf" MSC, reveal a limited transient benefit following MSC administration (Lucchini et al., 2010). Partial responses and a CR that subsequently reflared were reported in this instance. The median MSC dose delivered was $1.2 \times 10^{6} / \mathrm{kg}$ (range $0.7-2.8 \times 10^{6} / \mathrm{kg}$ ) as a single infusion at a median of 5 months following transplant (range 1-10 months; Lucchini et al., 2010).

In contrast, significant improvements have been reported following MSC therapy in patients with sclerodermal-type chronic GvHD (Zhou et al., 2010). Patients with extensive skin changes and ulcers showed significant improvement when treated with four to eight intra-bone marrow injections of MSC at a dose of $1-2 \times 10^{7} \mathrm{MSC} / \mathrm{kg}$. One change noted following MSC administration and possibly associated with the improvement in the 
symptoms of chronic $\mathrm{G} v \mathrm{HD}$ was a reversal in the Th1 to Th2 lymphocyte ratio. The administration of MSC and improvement in chronic GvHD was associated with an increase in the proportion of Th1 lymphocytes and a reduction in the proportion of Th2 lymphocytes (Zhou et al., 2010).

\section{CONCERNS REGARDING THE USE OF FBS FOR THE EX VIVO CULTURE OF A CLINICAL-GRADE HUMAN MSC PRODUCT}

While FBS is widely used to supplement medium used to expand MSC in vitro there are concerns that the use of xenogeneic material may transmit infectious (viral or prion) agents and/or compromise the immunoprivileged nature of the MSC by the presence of antigenic xenogeneic proteins on their cell surface (Sundin et al., 2007). In light of these concerns, human-derived alternatives to FBS have been investigated including autologous and allogeneic human serum and human platelet lysate (Stute et al., 2004; Doucet et al., 2005; Lin et al., 2005; Shahdadfar et al., 2005; Muller et al., 2006; Kocaoemer et al., 2007; Bieback et al., 2009; Lucchini et al., 2010). While ex vivo expansion of human MSC in medium supplemented with autologous or allogeneic human serum is highly variable and unreliable (Oreffo et al., 1997; Kuznetsov et al., 2000; Yamaguchi et al., 2002; Shahdadfar et al., 2005), the use of pooled human platelet lysate (hHPL) has proven more consistent supporting both the growth and differential potential of MSC (Schallmoser et al., 2007; Bieback et al., 2009; Lucchini et al., 2010). Outside of the use of xenogeneic or allogeneic supplements for basal media, a number of defined serum-free media have been developed specifically for the culture of human MSC (e.g., MesenCult ${ }^{\circledR}$-XF, StemCell Technologies; Hartmann et al., 2010). Although extensive comparison remains to be performed, the performance of these specialized serum-free media is reported to be comparable to that obtained with media supplemented with FBS (Hartmann et al., 2010).

\section{REFERENCES}

Aggarwal, S., and Pittenger, M. F. (2005). Human mesenchymal stem cells modulate allogeneic immune cell responses. Blood 105, 1815-1822.

Auletta, J. J., Cooke, K. R., Solchaga, L. A., Deans, R. J., and vant Hof, W. (2010). Regenerative stromal cell therapy in allogeneic hematopoietic stem cell transplantation: current impact and future directions. Biol. Blood Marrow Transplant. 16, 891-906.

Beyth, S., Borovsky, Z., Mevorach, D., Liebergall, M., Gazit, Z., Aslan, H., Galun, E., and Rachmilewitz, J. (2005). Human mesenchymal stem cells alter antigen-presenting cell maturation and induce T-cell unresponsiveness. Blood 105, 2214-2219.

Bieback, K., Hecker, A., Kocaomer, A., Lannert, H., Schallmoser, K., Strunk, D., and Kluter, H. (2009). Human alternatives to fetal bovine serum for the expansion of mesenchymal stromal cells from bone marrow. Stem Cells 27, 2331-2341.

Casiraghi, F., Azzollini, N., Cassis, P., Imberti, B., Morigi, M., Cugini, D.,
Cavinato, R. A., Todeschini, M., Solini, S., Sonzogni, A., Perico, N., Remuzzi, G., and Noris, M. (2008). Pretransplant infusion of mesenchymal stem cells prolongs the survival of a semiallogeneic heart transplant through the generation of regulatory T cells. J. Immunol. 181, 3933-3946.

Chapel, A., Bertho, J. M., Bensidhoum, M., Fouillard, L., Young, R. G., Frick, J., Demarquay, C., Cuvelier, F., Mathieu, E., Trompier, F., Dudoignon, N., Germain, C., Mazurier, C., Aigueperse, J., Borneman, J., Gorin, N. C., Gourmelon, P., and Thierry, D. (2003). Mesenchymal stem cells home to injured tissues when coinfused with hematopoietic cells to treat a radiation-induced multi-organ failure syndrome. J. Gene. Med. 5, 1028-1038.

Chung, N. G., Jeong, D. C., Park, S. J., Choi, B. O., Cho, B., Kim, H. K., Chun, C. S., Won, J. H., and Han, C. W. (2004). Cotransplantation of marrow stromal cells may prevent lethal graft-versushost disease in major histocompatibility complex mismatched murine

\section{SUMMARY}

Despite the evidence from in vitro MLR studies in multiple species demonstrating that MSC have immunomodulatory activity, and from well-defined mouse models demonstrating the ability of MSC to ameliorate the symptoms of GvHD and to improve survival following hematopoietic transplantation, attempts to duplicate these observations in a clinical hematopoietic transplantation setting have proven less successful. While this might be a consequence of suboptimal dosing and/or timing of MSC administration relative to the development of $\mathrm{G} v \mathrm{HD}$ in patients (factors highlighted as critical for efficacy by studies in mouse models), attempts to duplicate these observations in less welldefined animal (canine) hematopoietic transplantation models have similarly shown little benefit to the administration of MSC, despite the use of numerous dosing and timing variables. These inconsistencies indicate that further studies are required. Optimal culture and manufacturing conditions for the generation of sufficient numbers of an "off-the-shelf” GMP-grade MSC product need to be identified and standardized for MSC to provide an effective means by which to improve the significant mortality and morbidity currently associated with G $v \mathrm{HD}$. As discussed, while there are concerns associated with the use of xenogeneic fetal serum for the culture of human MSC, MSC growth in allogeneic human serum is unreliable. Alternatives to the use of xenogeneic or human sera to supplement basal media include the use of human platelet lysate (hHPL) which provides factors necessary for MSC growth, while more complex serum-free proprietary media are also becoming available. More multicenter clinical trials with well-defined protocols, GMP-grade MSC products and clinical endpoints will ultimately allow for a better understanding of the potential therapeutic potential of MSC to evolve for the treatment of $\mathrm{G} v \mathrm{HD}$ following hematopoietic transplantation.

hematopoietic stem cell transplantation. Int. J. Hematol. 80, 370-376.

Croitoru-Lamoury, J., Lamoury, F. M., Zaunders, J. J., Veas, L. A., and Brew, B. J. (2007). Human mesenchymal stem cells constitutively express chemokines and chemokine receptors that can be upregulated by cytokines, IFN-beta, and Copaxone. J. Interferon Cytokine Res. 27, 53-64.

Deans, R. J., and Moseley, A. B. (2000) Mesenchymal stem cells: biology and potential clinical uses. Exp. Hematol. 28, 875-884.

Devine, S. M., Cobbs, C., Jennings, M., Bartholomew, A., and Hoffman, R. (2003). Mesenchymal stem cells distribute to a wide range of tissues following systemic infusion into nonhuman primates. Blood 101, 2999-3001.

Di Ianni, M., Del Papa,B., De Ioanni, M., Moretti, L., Bonifacio, E., Cecchini, D., Sportoletti, P., Falzetti, F., and Tabilio, A. (2008). Mesenchymal cells recruit and regulate T regulatory cells. Exp. Hematol. 36, 309-318.

Di Nicola, M., Carlo-Stella, C., Magni, M., Milanesi, M., Longoni, P. D.,
Matteucci, P., Grisanti, S., and Gianni, A. M. (2002). Human bone marrow stromal cells suppress T-lymphocyte proliferation induced by cellular or nonspecific mitogenic stimuli. Blood 99, 3838-3843.

Dominici, M., Le Blanc, K., Mueller, I., Slaper-Cortenbach,I., Marini, F., Krause, D., Deans, R., Keating, A., Prockop, D., and Horwitz, E. (2006). Minimal criteria for defining multipotent mesenchymal stromal cells. The International Society for Cellular Therapy position statement. Cytotherapy 8, 315-317.

Doucet, C., Ernou, I., Zhang, Y., Llense, J. R., Begot, L., Holy, X., and Lataillade, J. J. (2005). Platelet lysates promote mesenchymal stem cell expansion: a safety substitute for animal serum in cell-based therapy applications. J. Cell. Physiol. 205, 228-236.

Fang, B., Song, Y., Zhao, R. C., Han, Q., and Lin, Q. (2007). Using human adipose tissue-derived mesenchymal stem cells as salvage therapy for hepatic graft-versus-host disease resembling acute hepatitis. Transplant. Proc. 39, 1710-1713. 
Gao, J., Dennis, J. E., Muzic, R. F., Lundberg, M., and Caplan, A. I. (2001). The dynamic in vivo distribution of bone marrow-derived mesenchymal stem cells after infusion. Cells Tissues Organs. 169, 12-20.

Gonzalez-Rey, E., Gonzalez, M.A., Varela, N., O’Valle, F., Hernandez-Cortes, P., Rico, L., Buscher, D., and Delgado, M. (2010). Human adipose-derived mesenchymal stem cells reduce inflammatory and $\mathrm{T}$ cell responses and induce regulatory $\mathrm{T}$ cells in vitro in rheumatoid arthritis. Ann. Rheum. Dis. 69, 241-248.

Gur-Wahnon, D., Borovsky, Z., Beyth, S., Liebergall, M., and Rachmilewitz, J. (2007). Contact-dependent induction of regulatory antigen-presenting cells by human mesenchymal stem cells is mediated via STAT3 signaling. Exp. Hematol. 35, 426-433.

Hartmann, I., Hollweck, T., Haffner, S., Krebs, M., Meiser, B., Reichart, B., and Eissner, G. (2010). Umbilical cord tissue-derived mesenchymal stem cells grow best under GMP-compliant culture conditions and maintain their phenotypic and functional properties. J. Immunol. Methods 363, 80-89.

Horwitz, E. M., Gordon, P. L., Koo, W. K., Marx, J. C., Neel, M. D., McNall, R. Y., Muul, L., and Hofmann, T. (2002). Isolated allogeneic bone marrowderived mesenchymal cells engraft and stimulate growth in children with osteogenesis imperfecta: implications for cell therapy of bone. Proc. Natl. Acad. Sci. U.S.A. 99, 8932-8937.

Horwitz, E. M., Le Blanc, K., Dominici, M., Mueller, I., Slaper-Cortenbach, I., Marini, F. C., Deans, R. J., Krause, D. S., and Keating, A. (2005). Clarification of the nomenclature for MSC: The International Society for Cellular Therapy position statement. Cytotherapy 7, 393-395.

Jiang, Y., Jahagirdar, B. N., Reinhardt, R. L., Schwartz, R. E., Keene, C. D., OrtizGonzalez, X. R., Reyes, M., Lenvik, T., Lund, T., Blackstad, M., Du, J., Aldrich, S., Lisberg, A., Low, W. C., Largaespada, D. A., and Verfaillie, C. M. (2002). Pluripotency of mesenchymal stem cells derived from adult marrow. Nature 418, 41-49.

Joo, S. Y., Cho, K. A., Jung, Y. J., Kim, H. S., Park, S. Y., Choi, Y. B., Hong, K. M., Woo, S. Y., Seoh, J. Y., Cho, S. J., and Ryu, K. H. (2010). Mesenchymal stromal cells inhibit graft-versus-host disease of mice in a dose-dependent manner. Cytotherapy 12, 361-370.

Joo, S. Y., Cho, K. A., Jung, Y. J., Kim, H. S., Park, S. Y., Choi, Y. B., Hong, K. M., Woo, S. Y., Seoh, J. Y., and Ryu, K. H. (2011). Bioimaging for the monitoring of the in vivo distribution of infused mesenchymal stem cells in a mouse model of the graft-versus-host reaction. Cell Biol. Int. 35, 417-421.

Kavanagh, H., and Mahon, B. P. (2011). Allogeneic mesenchymal stem cells prevent allergic airway inflammation by inducing murine regulatory $\mathrm{T}$ cells. Allergy 66, 523-531.

Keating,A. (2008). How do mesenchymal stromal cells suppress T cells? Cell Stem Cell 2, 106-108.

Kebriaei, P., Isola, L., Bahceci, E., Holland, K., Rowley, S., McGuirk, J., Devetten, M., Jansen, J., Herzig, R., Schuster, M., Monroy, R., and Uberti, J. (2009). Adult human mesenchymal stem cells added to corticosteroid therapy for the treatment of acute graft-versus-host disease. Biol. Blood Marrow Transplant. 15, 804-811.

Kocaoemer, A., Kern, S., Kluter, H., and Bieback, K. (2007). Human AB serum and thrombin-activated platelet-rich plasma are suitable alternatives to fetal calf serum for the expansion of mesenchymal stem cells from adipose tissue. Stem Cells 25, 1270-1278.

Kurtzberg, J., Prasad, V., Grimley, M. S., Horn, B., Carpenter, P. A., Jacobsen, D., and Prockop, S. (2009). Allogeneic Himan Mesenchymal Stem Cell Therapy (Prochymal) As A Rescue Agent For Severe Treatment Resistant GVHD in Pediatric Patients. Orlando, FL: American Society of Blood and Marrow Transplantation.

Kuznetsov, S. A., Mankani, M. H., and Robey, P. G. (2000). Effect of serum on human bone marrow stromal cells: ex vivo expansion and in vivo bone formation. Transplantation 70 , 1780-1787.

Le Blanc, K., Frassoni, F., Ball, L., Locatelli, F., Roelofs, H., Lewis, I., Lanino, E., Sundberg, B., Bernardo, M. E., Remberger, M., Dini, G., Egeler, R. M., Bacigalupo, A., Fibbe, W., and Ringden, O. (2008). Mesenchymal stem cells for treatment of steroidresistant, severe, acute graft-versushost disease: a phase II study. Lancet 371, 1579-1586.

Le Blanc, K., Rasmusson, I., Sundberg, B., Gotherstrom, C., Hassan, M., Uzunel, M., and Ringden, O. (2004). Treatment of severe acute graft-versus-host disease with third party haploidentical mesenchymal stem cells. Lancet 363, 1439-1441

Le Blanc, K., Tammik, L., Sundberg, B., Haynesworth, S. E., and Ringden, O. (2003). Mesenchymal stem cells inhibit and stimulate mixed lymphocyte cultures and mitogenic responses independently of the major histocompatibility complex. Scand. J. Immunol. 57, 11-20.

Lee, R. H., Pulin, A. A., Seo, M. J., Kota, D. J., Ylostalo, J., Larson, B. L., Semprun-Prieto, L., Delafontaine, P., and Prockop, D. J. (2009). Intravenous hMSCs improve myocardial infarction in mice because cells embolized in lung are activated to secrete the antiinflammatory protein TSG-6. Cell Stem Cell 5, 54-63.

Li, J., Zhu, H., Liu, Y., Li, Q., Lu, S., Feng, M., Xu, Y., Huang, L., Ma, C., An, Y., Zhao, R. C., Wang, R., and Qin, C. (2010). Human mesenchymal stem cell transplantation protects against cerebral ischemic injury and upregulates interleukin-10 expression in Macacafascicularis. Brain Res. 1334, 65-72.

Lin, H. T., Tarng, Y. W., Chen, Y. C., Kao, C. L., Hsu, C. J., Shyr, Y. M., Ku, H. H., and Chiou, S. H. (2005). Using human plasma supplemented medium to cultivate human bone marrow-derived mesenchymal stem cell and evaluation of its multiplelineage potential. Transplant. Proc. 37, 4504-4505.

Lucchini, G., Introna, M., Dander, E., Rovelli, A., Balduzzi, A., Bonanomi, S., Salvade, A., Capelli, C., Belotti, D., Gaipa, G., Perseghin, P., Vinci, P., Lanino, E., Chiusolo, P., Orofino, M. G., Marktel, S., Golay, J., Rambaldi, A., Biondi, A., D’Amico, G., and Biagi, E. (2010). Platelet-lysate-expanded mesenchymal stromal cells as a salvage therapy for severe resistant graft-versus-host disease in a pediatric population. Biol. Blood Marrow Transplant. 16, 1293-1301.

Majore, I., Moretti, P., Stahl, F., Hass, R., and Kasper, C. (2011). Growth and differentiation properties of mesenchymal stromal cell populations derived from whole human umbilical cord. Stem. Cell Rev. 7, 17-31.

Martin, B. J., Uberti, J. P., Soiffer, R. J., Klingemann, H., Waller, E. K., Daly, A. S., Herrmann, R. P., and Kebriaei, P. (2010). Prochymal Improves Response Rates In Patients With Steroid-Refractory Acute Graft Versus Host Disease (SR-GVHD) Involving The Liver And Gut: Results Of A Randomized, Placebo-Controlled, Multicenter Phase Iii Trial In GVHD. Orlando, FL: Amercian Society of Bone Marrow Transplantation.

McNiece, I., Harrington, J., Turney, J., Kellner, J., and Shpall, E. J. (2004). Ex vivo expansion of cord blood mononuclear cells on mesenchymal stem cells. Cytotherapy 6, 311-317.

Mielcarek, M., Storb, R., Georges, G. E., Golubev, L., Nikitine, A., Hwang, B., Nash, R. A., and Torok-Storb, B. (2011). Mesenchymal stromal cells fail to prevent acute graft-versus-host disease and graft rejection after dog leukocyte antigen-haploidentical bone marrow transplantation. Biol. Blood Marrow Transplant. 17, 214-225.
Min, C. K., Kim, B. G., Park, G., Cho, B. and Oh,I.H. (2007) IL-10-transduced bone marrow mesenchymal stem cells can attenuate the severity of acute graft-versus-host disease after experimental allogeneic stem cell transplantation. Bone Marrow Transplant. 39, 637-645.

Muller, I., Kordowich, S., Holzwarth, C., Isensee, G., Lang, P., Neunhoeffer, F., Dominici, M., Greil, J., and Handgretinger, R. (2008). Application of multipotent mesenchymal stromal cells in pediatric patients following allogeneic stem cell transplantation. Blood Cells Mol. Dis. 40, 25-32.

Muller, I., Kordowich, S., Holzwarth, C., Spano, C., Isensee, G., Staiber, A., Viebahn, S., Gieseke, F., Langer, H., Gawaz, M. P., Horwitz, E. M., Conte, P., Handgretinger, R., and Dominici, M. (2006).Animal serum-free culture conditions for isolation and expansion of multipotent mesenchymal stromal cells from human BM. Cytotherapy 8, 437-444.

Najar, M., Raicevic, G., Boufker, H. I., Fayyad Kazan, H., De Bruyn, C., Meuleman, N., Bron, D., Toungouz, M., and Lagneaux, L. (2010a). Mesenchymal stromal cells use PGE2 to modulate activation and proliferation of lymphocyte subsets: Combined comparison of adipose tissue, Wharton's Jelly and bone marrow sources. Cell Immunol. 264, 171-179.

Najar, M., Raicevic, G., Boufker, H. I., Fayyad-Kazan, H., De Bruyn, C., Meuleman, N., Bron, D., Toungouz, M., and Lagneaux, L. (2010b). Adipose-tissue-derived and Wharton's jelly-derived mesenchymal stromal cells suppress lymphocyte responses by secreting leukemia inhibitory factor. Tissue Eng. Part A 16, 3537-3546.

New, J. Y., Li, B., Koh, W. P., Ng, H. K., Tan, S. Y., Yap, E. H., Chan, S. H., and Hu, H. Z. (2002). T cell infiltration and chemokine expression: relevance to the disease localization in murine graft-versus-host disease. Bone Marrow Transplant. 29, 979-986.

Oreffo, R. O., Virdi, A. S., and Triffitt, J. T. (1997). Modulation of osteogenesis and adipogenesis by human serum in human bone marrow cultures. Eur. J. Cell Biol. 74, 251-261.

Osiris Therapeutics, Inc. (2009). Osiris therapeutics announces preliminary results for prochymal phase III GvHD trials. Available at: http://investor. osiris.com/

Pittenger, M. F., Mackay, A. M., Beck, S. C., Jaiswal, R. K., Douglas, R., Mosca, J. D., Moorman, M.A., Simonetti, D. W., Craig, S., and Marshak, D. R. (1999). Multilineage potential of adult human mesenchymal stem cells. Science 284 , 143-147. 
Pittenger, M. F., and Martin, B. J. (2004). Mesenchymal stem cells and their potential as cardiac therapeutics. Circ. Res. 95, 9-20.

Polchert, D., Sobinsky, J., Douglas, G., Kidd, M., Moadsiri, A., Reina, E., Genrich, K., Mehrotra, S., Setty, S., Smith, B., and Bartholomew, A. (2008). IFN-gamma activation of mesenchymal stem cells for treatment and prevention of graft versus host disease. Eur. J. Immunol.38, 1745-1755.

Prevosto, C., Zancolli, M., Canevali, P., Zocchi, M. R., and Poggi, A. (2007). Generation of CD4+ or CD8+ regulatory $\mathrm{T}$ cells upon mesenchymal stem cell-lymphocyte interaction. Haematologica 92, 881-888.

Prockop, D. J., and Olson, S. D. (2007). Clinical trials with adult stem/progenitor cells for tissue repair: let's not overlook some essential precautions. Blood 109, 3147-3151.

Ramasamy, R., Tong, C. K., Seow, H. F., Vidyadaran, S., and Dazzi, F. (2008). The immunosuppressive effects of human bone marrow-derived mesenchymal stem cells target $\mathrm{T}$ cell proliferation but not its effector function. Cell Immunol. 251, 131-136.

Ringden, O., Uzunel, M., Rasmusson, I., Remberger, M., Sundberg, B., Lonnies, H., Marschall,H.U., Dlugosz,A., Szakos, A., Hassan, Z., Omazic, B., Aschan, J., Barkholt, L., and Le Blanc, K. (2006). Mesenchymal stem cells for treatment of therapy-resistant graft-versus-host disease. Transplantation 81, 1390-1397.

Robinson, S. N., Ng, J., Niu, T., Yang, H., McMannis, J. D., Karandish, S., Kaur, I., Fu, P., Del Angel, M., Messinger, R., Flagge, F., de Lima, M., Decker, W., Xing, D., Champlin, R., and Shpall, E. J. (2006). Superior ex vivo cord blood expansion following co-culture with bone marrow-derived mesenchymal stem cells. Bone Marrow Transplant. 37, 359-366.

Schallmoser, K., Bartmann, C., Rohde, E., Reinisch,A., Kashofer, K., Stadelmeyer, E., Drexler, C., Lanzer, G., Linkesch, W., and Strunk, D. (2007). Human platelet lysate can replace fetal bovine serum for clinical-scale expansion of functional mesenchymal stromal cells. Transfusion 47, 1436-1446.
Shahdadfar, A., Fronsdal, K., Haug, T., Reinholt, F. P., and Brinchmann, J. E. (2005). In vitro expansion of human mesenchymal stem cells: choice of serum is a determinant of cell proliferation, differentiation, gene expression, and transcriptome stability. Stem Cells 239, 1357-1366.

Shlomchik, W. D. (2007). Graft-versushost disease. Nat. Rev. Immunol. 7, 340-352.

Spaggiari, G. M., Capobianco, A., Becchetti, S., Mingari, M. C., and Moretta, L. (2006). Mesenchymal stem cell-natural killer cell interactions: evidence that activated NK cells are capable of killing MSCs, whereas MSCs can inhibit IL-2-induced NK-cell proliferation. Blood 107, 1484-1490.

Stute, N., Holtz, K., Bubenheim, M., Lange, C., Blake, F., and Zander, A. R. (2004). Autologous serum for isolation and expansion of human mesenchymal stem cells for clinical use. Exp. Hematol. 32, 1212-1225.

Sudres, M., Norol, F., Trenado, A., Gregoire, S., Charlotte, F., Levacher, B., Lataillade, J. J., Bourin, P., Holy, X., Vernant, J. P., Klatzmann, D., and Cohen, J.L. (2006). Bone marrow mesenchymal stem cells suppress lymphocyte proliferation in vitro but fail to prevent graft-versus-host disease in mice. J. Immunol. 176, 7761-777.

Sundin, M., Barrett, A. J., Ringden, O., Uzunel, M., Lonnies, H., Dackland, A. L., Christensson, B., and Blanc, K. L. (2009). HSCT recipients have specific tolerance to MSC but not to the MSC donor. J. Immunother. 32, 755-764.

Sundin, M., Ringden, O., Sundberg, B., Nava, S., Gotherstrom, C., and Le Blanc, K. (2007). No alloantibodies against mesenchymal stromal cells, but presence of anti-fetal calf serum antibodies, after transplantation in allogeneic hematopoietic stem cell recipients. Haematologica 929, 1208-1215.

Tisato, V., Naresh, K., Girdlestone, J., Navarrete, C., and Dazzi, F. (2007). Mesenchymal stem cells of cord blood origin are effective at preventing but not treating graft-versus-host disease. Leukemia 21, 1992-1999.
Toma, C., Pittenger, M. F., Cahill, K. S. Byrne, B. J., and Kessler, P. D. (2002). Human mesenchymal stem cells differentiate to a cardiomyocyte phenotype in the adult murine heart. Circulation 105, 93-98.

Tong, C. K., Vellasamy, S., Tan, B. C., Abdullah, M., Vidyadaran, S., Seow, H. F., and Ramasamy, R. (2010). Generation of mesenchymal stem cell from human umbilical cord tissue using combination of enzymatic and mechanical disassociation method. Cell Biol. Int. 35, 221-226.

Uccelli, A., Moretta, L., and Pistoia, V. (2008). Mesenchymal stem cells in health and disease. Nat. Rev. Immunol. 8, 726-736.

von Bonin, M., Stolzel, F., Goedecke, A., Richter, K., Wuschek, N., Holig, K., Platzbecker, U., Illmer, T., Schaich, M., Schetelig, J., Kiani, A., Ordemann, R., Ehninger, G., Schmitz, M., and Bornhauser, M. (2009). Treatment of refractory acute GVHD with thirdparty MSC expanded in platelet lysatecontaining medium. Bone Marrow Transplant. 43, 245-251.

Wang, L., Li, Y., Chen, X., Chen, J., Gautam, S. C., Xu, Y., and Chopp, M. (2002). MCP-1, MIP-1, IL-8 and ischemic cerebral tissue enhance human bone marrow stromal cell migration in interface culture. Hematology 7, 113-117.

Welniak, L. A., Blazar, B. R., and Murphy, W. J. (2007). Immunobiology of allogeneic hematopoietic stem cell transplantation. Annu. Rev. Immunol. 25, 139-170.

Weng, J. Y., Du, X., Geng, S. X., Peng, Y. W., Wang, Z., Lu, Z. S., Wu, S. J., Luo, C. W., Guo, R., Ling, W., Deng, C. X., Liao, P. J., and Xiang, A. P. (2010). Mesenchymal stem cell as salvage treatment for refractory chronic GVHD. Bone Marrow Transplant. 45, 1732-1740.

Yamaguchi, M., Hirayama, F., Wakamoto, S., Fujihara, M., Murahashi, H., Sato, N., Ikebuchi, K., Sawada, K., Koike, T., Kuwabara, M., Azuma, H., and Ikeda, H. (2002). Bone marrow stromal cells prepared using $\mathrm{AB}$ serum and $\mathrm{bFGF}$ for hematopoietic stem cells expansion. Transfusion 42, 921-927.
Ye, Z., Wang, Y., Xie, H. Y., and Zheng, S. S. (2008). Immunosuppressive effects of rat mesenchymal stem cells: involvement of CD4+CD25+ regulatory $\mathrm{T}$ cells. Hepatobiliary Pancreat. Dis. Int. 7, 608-614.

Zhang, Y., Li, C., Jiang, X., Zhang, S., Wu, Y., Liu, B., Tang, P., and Mao, N. (2004a). Human placenta-derived mesenchymal progenitor cells support culture expansion of long-term culture-initiating cells from cord blood CD34+ cells. Exp. Hematol. 32, 657-664.

Zhang, W., Ge, W., Li, C., You, S., Liao, L., Han, Q., Deng, W., and Zhao, R. C. (2004b). Effects of mesenchymal stem cells on differentiation, maturation, and function of human monocytederived dendritic cells. Stem Cells Dev. 13, 263-271.

Zhou, H., Guo, M., Bian, C., Sun, Z., Yang, Z., Zeng, Y., Ai, H., and Zhao, R.C. (2010). Efficacy of bone marrowderived mesenchymal stem cells in the treatment of sclerodermatous chronic graft-versus-host disease: clinical report. Biol. Blood Marrow Transplant. $16,403-412$.

Conflict of Interest Statement: The authors declare that the research was conducted in the absence of any commercial or financial relationships that could be construed as a potential conflict of interest.

Received: 25 May 2011; accepted: 21 June 2011; published online: 04 July 2011.

Citation: Kebriaei $P$ and Robinson S (2011) Mesenchymal stem cell therapy in the treatment of acute and chronic graft versus host disease. Front. Oncol. 1:16. doi:10.3389/fonc.2011.00016

This article was submitted to Frontiers in Hematology Oncology, a specialty of Frontiers in Oncology.

Copyright (C) 2011 Kebriaei and Robinson. This is an open-access article subject to a non-exclusive license between the authors and Frontiers Media SA, which permits use, distribution and reproduction in other forums, provided the original authors and source are credited and other Frontiers conditions are complied with. 